\title{
Assessing sodium limitation as a resource for ground-dwelling ants (Hymenoptera: Formicidae) in an area of the Amazonian Terra Firme Forest
}

\section{Avaliando a limitação de sódio como recurso para formigas de solo (Hymenoptera: Formicidae) em uma área de floresta amazônica de Terra Firme}

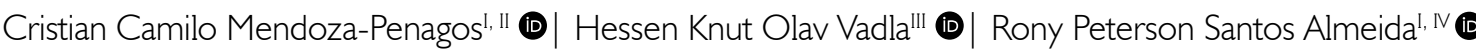 \\ Universidade Federal do Pará. Programa de Pós-Graduação em Zoologia. Belém, Pará, Brasil \\ "Universidade Federal do Pará. Laboratório de Ecologia e Conservação. Belém, Pará, Brasil \\ I'U University of Oslo. Postgraduate Program in Ecology. Oslo, Noruega \\ IvMuseu Paraense Emílio Goeldi/MCTIC. Coordenação de Ciências da Terra e Ecologia. Belém, Pará, Brasil
}

\begin{abstract}
The availability of nutrients in the soil acts as a filter in the ants that inhabit this layer, affecting their foraging patterns and showing preferences or limitations on their nutritional needs. Especially in environments far from the ocean, the salt deficit can be a limiting resource in the environment. Here, we test whether changes in species richness and composition reveal food preferences for ants that inhabit the soil, using sugar and salt as attractions in an area of the Amazon Forest. In total, 21 species in nine genera were collected; all species were collected in sugar and only two in salt. In addition to the ant richness eleven times greater in sugar, the composition differed between the attractions. Our results indicate that the litter ants in the preserved forest are not limited by availability of sodium and they prefer sugar to salt as attractant, even with this environment far from the coast.
\end{abstract}

Keywords: Caxiuanã. Bait. Food preference. Amazon rainforest. Assembly.

Resumo: A disponibilidade dos nutrientes no solo atua como um filtro nas formigas que habitam essa camada, afetando seus padrões de forrageamento e mostrando preferências ou limitações em suas necessidades nutricionais. Sobretudo em ambientes distantes do oceano, o déficit salino pode ser um recurso limitante no ambiente. Aqui, testamos se mudanças na riqueza e na composição das espécies revelam preferências alimentares de formigas que habitam o solo, usando açúcar e sal como atrativos em uma área da floresta amazônica. No total, 21 espécies em nove gêneros foram coletadas; todas as espécies foram coletadas no açúcar e apenas duas no sal. Além da riqueza de formigas onze vezes maior no açúcar, a composição diferiu entre os atrativos. Nossos resultados indicam que as formigas da serapilheira na floresta preservada não são limitadas pela disponibilidade de sódio, preferindo o açúcar ao sal como recurso, mesmo com esse ambiente distante do litoral.

Palavras-chave: Caxiuanã. Isca. Preferência alimentar. Floresta amazônica. Assembleia.

\footnotetext{
MENDOZA-PENAGOS, C. C., H. K. O. VADLA \& R. P. S. ALMEIDA, 2020. Assessing sodium limitation as a resource for ground-dwelling ants (Hymenoptera: Formicidae) in an area of the Amazonian Terra Firme Forest. Boletim do Museu Paraense Emílio Goeldi. Ciências Naturais 15(1): 135-143. DOI: http://doi.org/10.46357/bcnaturais.v15i1.269.

Autor para correspondência: Cristian Camilo Mendoza-Penagos. Universidade Federal do Pará. Instituto de Ciências Biológicas. Laboratório de Ecologia e Conservação (LABECO). Av. Perimetral 2-224 - Guamá. Belém, PA, Brasil. CEP 66075-110 (cris_kmlo@hotmail.com).

Recebido em 29/01/2020

Aprovado em 10/04/2020

Responsabilidade editorial: Lívia Pires do Prado
}
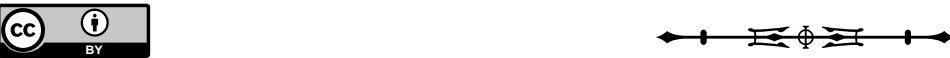


\section{INTRODUCTION}

The acquisition of nutritional resources is one of the first challenges faced by all organisms to be able to perform essential processes such as survival, growth and reproduction. However, the availability of foods can vary within and between different habitats, because nutrients are heterogeneously distributed, presenting variations that affect the communities (Yavitt et al., 2009; Dorian \& Bonoan, 2016). Hence, activities like foraging and recruitment of nutritional resources from the environment must be essential to maintain life processes (Feldhaar, 2014).

In contrast to solitary animals, the ingestion of nutrients in social insects has additional levels of complexity. Not only must they collect food that satisfies their individual nutritionals needs, they also forage for other members of the colony (Dussutour \& Simpson, 2008; Feldhaar, 2014; Csata \& Dussutour, 2019). Although this retransmission ratio is poorly understood, differences in the nutrients that make up the diet, seem to influence body composition, e.g., protein-fed worker ants showed significantly higher levels of phosphorus in their body mass, while workers fed excess sucrose had a higher C:N ratio (Feldhaar, 2014). Ants are ideal organisms for the study of recruitment and foraging due to their eusocial organization strategy, their wide range of foraging habits associated with other organisms (Hölldobler \& Wilson, 1990) and due to their vast distribution in the most of the land ecosystems, reaching the highest diversity level in the tropics (Fernández, 2003; Bolton, 2018).

Since most ants have an omnivorous diet, they are usually attracted to resources with higher levels of sugar as principal food source (Tinti \& Nofre, 2001). It has been demonstrated that some ants are consuming resources with mixtures of sugar and amino acids, like extrafloral nectar (NEF's) (Lanza et al., 1993). These structures are associated with some plants, and one of their functions is to present a source of sugar for ants, in exchange for protection against predators (Blüthgen \& Fiedler, 2004; Feldhaar, 2014). However, several studies indicate that salt could be acting as a limiting resource, for ants with diets poor in salt (Kaspari et al., 2009; O'Donnell et al., 2010). Sodium ( $\mathrm{Na})$ is a vital nutrient for ants in maintenance of biological processes like osmotic balance in cells, neurotransmission, and muscles movement (Kaspari et al., 2008). As a result, ants are foraging minerals from different sources to supplement their diets with additional sodium.

In tropical rainforests far from the ocean (e. g. more than $300 \mathrm{~km}$ from the coastline to continental shelf), salt may be a limited soil resource (Peña-Venegas \& Vanegas, 2010; Dudley et al., 2012) and hence influence species richness and composition (Moreira et al., 2012). In places with low sodium inputs and higher rates of Net Primary Productivity (NPP), ants are shown to be more attracted to salt baits, and recruitment is higher when higher concentrations are used (Kaspari et al., 2009, 2008). That's effects are specifically marked in green food web ants, because their diets are based mainly on abundant vegetation, so to increase and satisfy their sodium necessity they must be consume higher quantities of food with lower concentration of sodium (Kaspari et al., 2019; Viera \& Vasconcelos, 2014). Furthermore, when sampling ant communities, there is little concern with the nutritional need of ants in different environments. Collection protocols already established, with sardine (protein resource) and diluted honey (caloric resource) are commonly used, but rarely salt (Schmidt \& Diehl, 2008; Vicente et al., 2018).

Since the availability of food resources in ants influences their distributions and foraging patterns (Feldhaar, 2014) and taking into account that environments far from the ocean have sodium limitations, the objective of this study was to evaluate whether there are sodium limitations for the ant community present in the litter in an Amazon rainforest area. We hypothesized that (i) there will be a higher richness of species ants in salt baits than in sugar, since limitations of sodium in the environment would increase the demand for salt for the ants' physiological requirements. In addition, ii) the composition of ant species will be different between baits, influenced mainly by herbivorous ants, since this group needs to supplement salt in their diet (Kaspari et al., 2008).

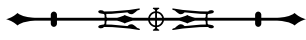




\section{MATERIAL AND METHODS}

\section{STUDY AREA}

The study was carried out in a humid tropical rainforest of Terra Firme close to Ferreira Penna Scientific Station (ECFPn) in the National Forest of Caxiuanã (FLONA of Caxiuanã), located in the municipality of Melgaço, in the northwest region of the state of Pará ( $01^{\circ} 42^{\prime}$ 30" S; $51^{\circ}$ 31' 45" W; 62 m.a.s.l.) (Figure 1). The total area of the FLONA is 330,000 ha and ECFPn represents around of $10 \%$ total area (Oliveira, L. et al., 2008). The distance from the Atlantic sea is around $420 \mathrm{~km}$ (Oliveira, L. et al., 2008; ICMBio, 2012) and by the Köpen classification, the climate is a tropical hot and humid type and subtype 'Am' with a short dry season. The mean ambient temperature, and air temperature ranges around $26.7^{\circ} \mathrm{C}$ minimum and maximum of $22^{\circ} \mathrm{C}$ and $32{ }^{\circ} \mathrm{C}$, respectively (Oliveira, L. et al., 2008).

The vegetation presents a typical ecosystem of the Amazon rainforest, with areas of flooded forest (floodplain and igapó), stretches of secondary vegetation, savanoid vegetation, predominantly upland forest (Terra Firme), which occupies approximately $85 \%$ of the area. In the upland forest, canopy-cover habitats prevails over other forms of vegetation, and its understory vegetation is predominantely shaded, with a low incidence of direct light, except in the cracks between the tree canopies, and in the natural clearings (Lisboa \& Ferraz, 1999; Diniz \& Scudeller, 2005). The Caxiuanã soils range from well drained to moderately drained, sandy to loamy, acidic and poor in nutrients, with $\mathrm{pH}$ ranges from 3.5 (very acidic) to 5.5 (moderately acidic) (Oliveira, L. et al., 2008).

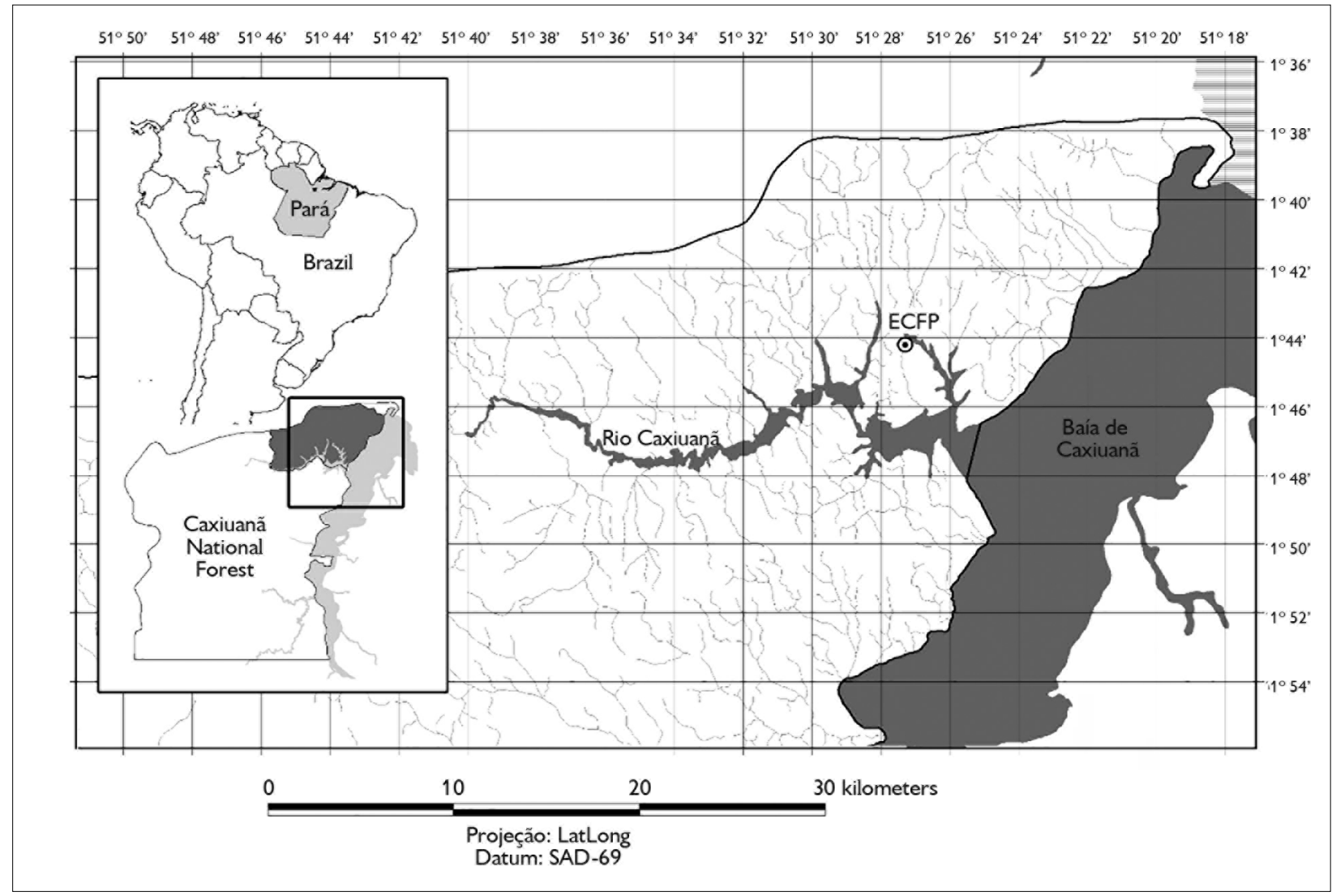

Figure 1. National Forest (FLONA) of Caxiuanã, Melgaço, Pará, Brazil, where specimens of ants. Map: MPEG/UAS/Project TEAM (2012).

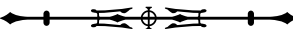




\section{DATA COLLECTION}

The ants were collected in eight lineal transects on day 8 of September of 2018. The sampling was made during all day beginning at 8 am and finished at $16 \mathrm{pm}$. Each transect had 4 plots, separated by $2 \mathrm{~m}$, making a total transect length of $6 \mathrm{~m}$. The eight transects were each separated by a minimum distance of $40 \mathrm{~m}$. Each plot received an microtube that contained the attractant (salt or sugar), being chosen at random for each plot. On total, we got 32 microtubes, 16 for each treatment.

We used $5 \mathrm{~mL}$ microtubes, where in each was placed a ball of paper before being filled with $2 \mathrm{~mL}$ of the attractant, salt or sugar. The sugar solutions were made with a concentration of $10 \%$ and salt solutions with concentration of $1 \%$ (weight/volume), diluting the attractive (sugar = $10 \mathrm{~g}$; salt = $1 \mathrm{~g}$ ) in $100 \mathrm{~mL}$ of water (Kaspari et al., 2008). The sugar baits were composed of sucrose $\left(\mathrm{C}_{12} \mathrm{H}_{22} \mathrm{O}_{11}\right)$, while the salt baits with common table salt $(\mathrm{NaCl})$. The microtubes were placed in the ground with the edge of the tube aligning the ground, after gently brushing aside leaf litter, and left sampling for 60 minutes, then closed, trapping all ants currently inside, filled with 70\% alcohol and marked. The ants were taken to the laboratory and identified with a taxonomic key for the genera (Baccaro et al., 2015) and compared with the reference material of the Laboratório de Morfologia e Ecologia Funcional de Formigas (AntMor) of the Museu Paraense Emilio Goeldi, where the individuals were deposited.

\section{STATISTICAL ANALYSIS}

To assess whether the richness of ants (response variable) differs between attractants (predictor variable) salt and sugar, a generalized linear model (GLM - Zar, 2010) was used, with each transect being considered as the sampling unit. After the evaluate the data distribution (Shapiro-Wilk $=0.859, p=0.019)$, the model was adjusted using a Poisson distribution family for data counting, and the log as a link function. An ANOVA test was made for testing the significance of the model, using a p-value of Chi-square test.
To evaluate if the composition of ant species varied between the attractants, we made a permutational multivariate analysis of variance (PERMANOVA Anderson, 2001). We did an ordination through a Principal Coordinates Analysis (PCoA), using the Jaccard dissimilarity index for presence-absences data (Legendre \& Legendre, 2012) and we eliminated sample units that did not have species collected. Subsequently, a similarity percentage analysis (SIMPER) was performed to know the contribution of each species within the PERMANOVA analysis, identifying which were the most important species within the observed similarity pattern.

All analyses were performed in the R software (R Development Core Team, 2018) and level of significance used was $p<0.05$. We use the functions / packages: 1) GLM: stats (R Development Core Team, 2018); 2) PERMANOVA and SIMPER: vegan (Oksanen et al., 2018); 3) figures: ggplot2 (Wickham, 2016) and gridExtra (Baptiste, 2017).

\section{RESULTS}

A total of belonging to 21 species (557 individuals) of ants distributed in 9 genera and 4 subfamilies were collected (Table 1). The genus with the largest number of species was Pheidole, representing more than half of the species collected. The most abundant species in the attractants were Pheidole biconstricta Mayr, 1870 (114 individuals), Pheidole sp.1 (113), Solenopsis sp.1 (79) and Crematogaster aff. levior (72). All species were collected in sugar attractant, and two of these in salt (Pachycondyla harpax (Fabricius, 1804) and Mayaponera constricta (Mayr, 1884)). In the sugar attractant, Odontomachus sp.1, Crematogaster aff. levior and Pheidole sp.1 were the species with highest values of occurrence, being presents in half of the samples.

The model fitted in GLM indicated that there is a significant difference in the richness of ants between the attractants (Deviance Resid. $_{(1,14)}=9.845 ; p<0.001$ ), with sugar presenting on mean 11 times more species than salt (Figure 2A). 
Table 1. Ant species collected in each treatment (sugar and salt) in the eight sampling units in an Terra Firme area of the Amazon Forest in the in Caxiuanã FLONA, Pará, Brazil. * = species that contributed more than $50 \%$ of the dissimilarity in composition between the attractants.

\begin{tabular}{|c|c|c|c|}
\hline \multirow{2}{*}{ Subfamily/Specie } & \multicolumn{2}{|c|}{ Relative frequency } & \multirow{2}{*}{ SIMPER (\%) } \\
\hline & Sugar & Salt & \\
\hline \multicolumn{4}{|l|}{ ECTATOMMINAE } \\
\hline Ectatomma sp.1 & 0.25 & - & 3.77 \\
\hline \multicolumn{4}{|l|}{ FORMICINAE } \\
\hline Camponotus sp.1 & 0.12 & - & 2.29 \\
\hline Nylanderia sp.1 & 0.38 & - & $6.79 *$ \\
\hline \multicolumn{4}{|l|}{ PONERINAE } \\
\hline Mayaponera constricta (Mayr, 1884) & 0.38 & 0.12 & $7.75 *$ \\
\hline Odontomachus sp.1 & 0.50 & - & $9.08^{*}$ \\
\hline Pachycondyla harpax (Fabricius, 1804) & 0.38 & 0.38 & $8.47 *$ \\
\hline \multicolumn{4}{|l|}{ MYRMICINAE } \\
\hline Crematogaster aff. levior & 0.50 & - & $6.91 *$ \\
\hline Ochetomyrmex neopolitus Fernández, 2003 & 0.25 & - & 3.76 \\
\hline Pheidole biconstricta Mayr, 1870 & 0.38 & - & $6.58^{*}$ \\
\hline Pheidole fracticeps Wilson, 2003 & 0.38 & - & 4.62 \\
\hline Pheidole schwarzmaieri Borgmeier, 1939 & 0.25 & - & 3.15 \\
\hline Pheidole subarmata Mayr, 1884 & 0.25 & - & 3.76 \\
\hline Pheidole aff. meinerti & 0.25 & - & 3.76 \\
\hline Pheidole aff. microps & 0.12 & - & 1.67 \\
\hline Pheidole MPEG_05 & 0.12 & - & 1.47 \\
\hline Pheidole gr. tristis MPEG_01 & 0.12 & - & 2.81 \\
\hline Pheidole gr. tachigaliae & 0.12 & - & 2.29 \\
\hline Pheidole sp.1 & 0.50 & - & $9.08 *$ \\
\hline Pheidole sp.2 & 0.12 & - & 1.47 \\
\hline Pheidole sp.3 & 0.12 & - & 2.29 \\
\hline Solenopsis sp.1 & 0.12 & - & 1.47 \\
\hline Richness & 21 & 2 & \\
\hline
\end{tabular}

The PERMANOVA analysis revealed that there exists a significant difference in the species composition between attractives (Pseudo- $F_{(1,11)}=2.709, R^{2}=0.213$; $\mathrm{p}=0.017$ ) (Figure 2B). The PCoA ordination captured a total of $58.849 \%$ of the variation in the data, in their first two axes (axis $1=34.260 \%$, axis $2=24.589 \%$ ) (Figure 2B). Of the 21 species recorded, 7 explain $50 \%$ of the differences in the composition between attractives
(Table 1). Odontomachus sp.1 and Pheidole sp.1 were the species that contributed the most to the difference between the attractants, with $9.08 \%$ each, and being present only in the sugar baits; followed by P. harpax (8.47\%) and $M$. constricta (7.75\%) that were present in both attractants, while Nylanderia sp.1, Crematogaster aff. levior e P. biconstricta contributed with around 6\%, only in sugar baits. 


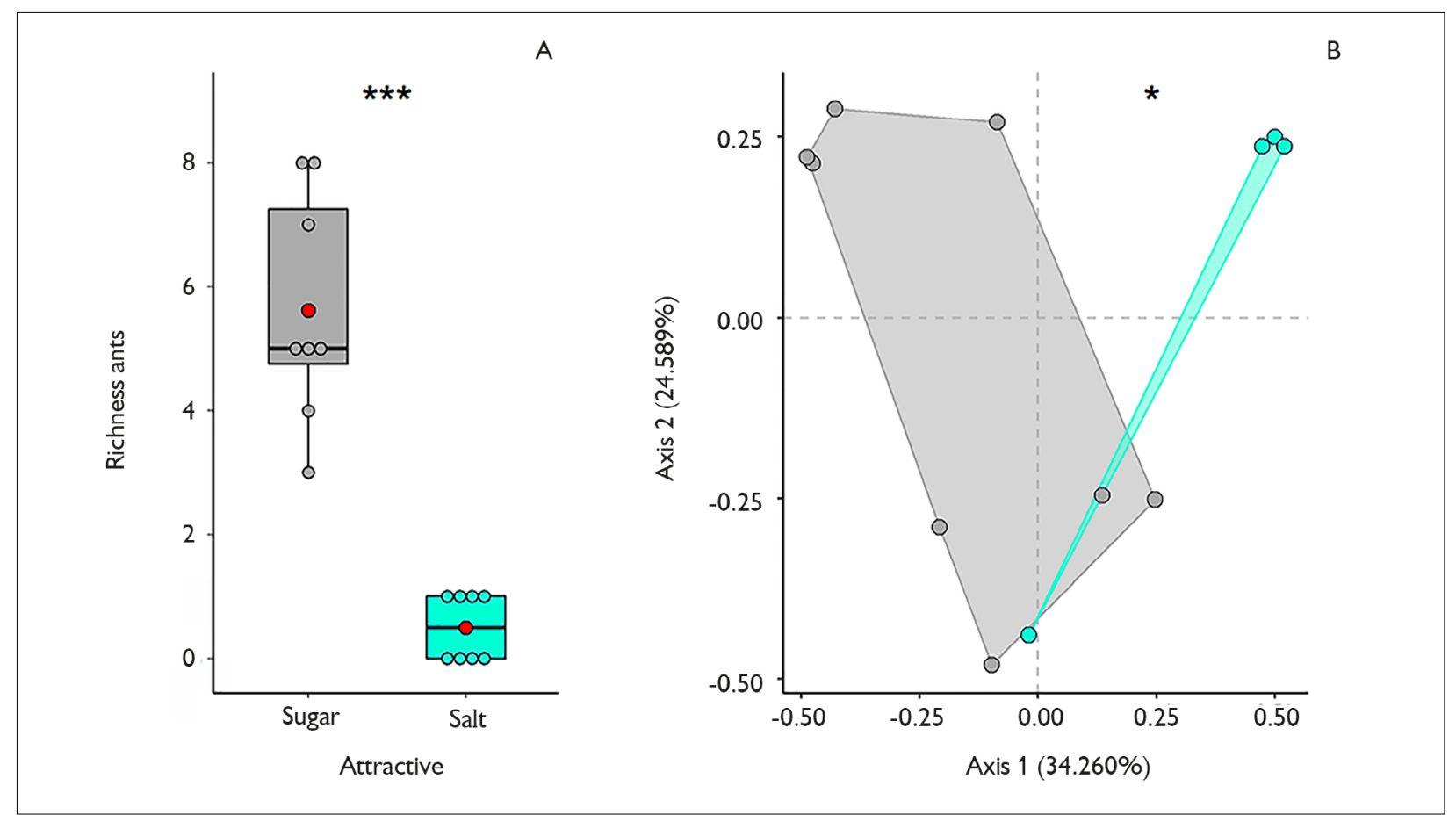

Figure 2. Community of ants collected in salt and sugar and effect of (A) richness and (B) composition of species collected in Terra Firme Amazon Rainforest in Caxiuanã FLONA, Pará, Brazil ( $p$ value in code *** $<0.001$ and $*<0.05$; red dots indicate the mean richness collected in each treatment).

\section{DISCUSSION}

Our results suggest that in the local of study, the grounddwelling ants are not limited by sodium availability, with only two species associated to salt baits. Hence, our first hypothesis was rejected, once the greater richness of species was recorded in sugar baits and not in salt baits. Our second hypothesis was partially confirmed. Once that exist difference in the species composition between baits, but contrary to our prediction the species associated with salt are carnivorous.

Species with generalist behavior respond faster to baits and were predominant in the ground-dwelling ants assembly. The relative dominance of the Myrmicinae subfamily in the area, and the fact that Pheidole genus were the most abundant in sugar baits, confirm this. Pheidole has been indicated as a generalist group of ants on land, with an omnivorous diet and aggressive behavior, aiding in the maintenance of large colonies, and in defending their resources against coexisting species (Baccaro et al., 2013).
Furthermore, the Ponerinae subfamily was the second most representative recorded species in both types of bait, and with higher frequency values, suggesting broad preferences for food resources. Their frequencies can be explained because they are the second most diverse ground-dwelling ants after Myrmicinae (AntWeb, 2019), and are a species commonly found on the ground of the Caxiuanã forest (Basto \& Harada, 2011).

The highest richness was found in the sugar baits, suggesting that the ground-dwelling ants were more attracted to sugar than salt. In fact, in tropical forests ants are more attracted to baits with a high carbohydrate (Longino et al., 2002; Bihn et al., 2008). Nevertheless, the availability of carbohydrates in old forests, or with old successional stages is lower for the dwelling-ground ants, causing ants to frequently increase their foraging activities in search of food, including climbing plants to reach the Extrafloral Nectaries (ENF's), and honeydew (excretions from herbivorous insects) 
(Oliveira, P. \& Brandão, 1991). ENF's have been indicated as a two important carbohydrate sources, but principally for arboreal ants (Schupp \& Feener, 1991); furthermore, their general occurrence in old-growth forests is lower in tropical areas, limiting their access and generating higher rates of competition (Fiala \& Linsenmair, 1995). In mature forests, leaf-litter ants are more attracted to carbohydrate baits, due to a general limitation of these nutrients (Bihn et al., 2008), or by their high recruitment and foraging ability when compared to salt-using ants (Vieira \& Vasconcelos, 2014). Hence, the success of sugar as an attractant, in this case, suggests little availability of sugar in the soil, which was quickly occupied by generalist and active foraging species.

Additionally, the low effectiveness of salt as an attractant indicates that ants living in the soil are not limited by salt. Salt baits, and the amount of ants associated with them, are used as evidence of sodium limitation, mainly in herbivorous ants (Vieira \& Vasconcelos, 2014). Even so, the sodium supply varies geographically, and there is a relationship between the distance from the coast to the interior of the continent and the attractiveness of ants to salt (Kaspariet al., 2008; Breed, 2015). Based on distance from forest to coast, the preference of ants for salt should be at least $20 \%$ of the total number of traps (Kaspari et al., 2008; Breed, 2015). Those predictions differ from our results ( $<1 \%$ ), which could be also attributed to geographic variation of availability of sodium in Amazon biome (Dudley et al., 2012) or to the fact that a salt concentration gradient was not used. In addition, no herbivore ant species were collected, such as mushroom growers, although they are genera commonly found in the litter (Harada, 2016).

Our results show differences in the composition of ground-dwelling ants, as could be identified using common sugar and salt. Hence, food resources can determine if there are differences in the composition of species in a given assembly (Bastos \& Harada, 2011; Nyamukondiwa \& Addison, 2014). Once ants forage and nest in accordance with local nutrient limitation and resource availability (McGlynn et al., 2007) it is expected that in heterogeneous environments such as the litter of the forests of Terra Firme, species with different nutritional requirements is found. Although the main differences in the composition are attributed to species with generalist behaviour, such as Pheidole, the presence of predatory species such as Odonotomachus, Mayaponera constricta and Pachycondyla harpax (Silva \& Brandão, 2014) made a great contribution to that difference. The presence of these species is not necessarily related to the use of a specific resource, but on the contrary it could show unmet nutritional needs with the base resource used by the species.

Finally, sugar appears to be a more effective attractant to ground-dwelling ants, than salt, despite the expected lack of salt in rainforests away from the ocean. Thus, more research must be done to understand how different food resources can be affect the ground ants assembly. Since the availability of food resources is heterogeneously distributed in time and space, future studies could explore ants preferences to food resources with different concentrations and variations along the seasons.

\section{CONCLUSION}

In the present study, our results indicate that the grounddwelling ants in a preserved rainforest are not limitated by availability of sodium and they prefer prefer sugar to salt as attractant. In addition, differences in the composition of the assembly can be detected based on food preferences once the number of individuals acts as a mirror of the availability or limitation of the resource experienced by the ants. These results suggest that the distance from the ocean may not directly reflect salt deficiency, and more studies are needed to evaluate the relationship between ant preference and the amount of salt available in the environment.

\section{ACKNOWLEDGMENTS}

Thanks to DPhil. Douglas Shiel, for ideas, inputs and suggestions during fieldwork and to four anonymous reviewers for the suggestions that contributed to this publication. We would also like to thank the postgraduate program in Zoology of the Federal University of Pará, the Conselho Nacional de Desenvolvimento Científico e

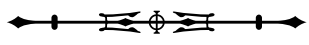


Tecnológico - CNPq, Emilio Goeldi Museum, Scientific Station Ferreira Penna for support during data collection, Norsk Hydro, the University of Oslo and the Biodiversity Research Consortium Brazil-Norway (BRC) for granting of the master's scholarships and general funding. This study was financed in part by the Coordenação de Aperfeiçoamento de Pessoal de Nível Superior - Brasil (CAPES) - Finance Code 001.

\section{REFERENCES}

ANDERSON, M. J., 2001. A new method for non-parametric multivariate analysis of variance. Austral Ecology 26(1): 32-46. DOI: https://doi.org/10.1111/J.1442-9993.2001.01070.pp.x.

ANTWEB, 2019. Available from: http://www.antweb.org. Accessed in: December 26, 2019.

BACCARO, F. B., I. F. ROCHA, B. E. G. DEL AGUILA, J. SCHIETTI, T. EMILIO, J. L. P. PURRI, A. P. LIMA \& W. E. MAGNUSSON, 2013. Changes in ground-dwelling ant functional diversity are correlated with water-table level in an Amazonian Terra Firme Forest. Biotropica 45(6): 755-763. DOI: https://doi.org/10.1111/btp.12055.

BACCARO, F. B., R. M. FEITOSA, F. FERNÁNDEZ, I. O. FERNANDES, T. J. IZZO, J. L. P. DE-SOUZA \& R. R. C. SOLAR, 2015. Guia para os gêneros de formigas do Brasil: 1-388. INPA, Manaus.

BAPTISTE, A., 2017. gridExtra: miscellaneous functions for "grid" graphics. R package version 2.3. Available from: https://CRAN.Rproject.org/package= gridExtra. Accessed in: December 26, 2019.

BASTOS, A. H. S. \& A. Y. HARADA, 2011. Leaf-litter amount as a factor in the structure of a ponerine ants community (Hymenoptera, Formicidae, Ponerinae) in an eastern Amazonian rainforest, Brazil. Revista Brasileira de Entomologia 55(4): 589-596. DOI: http:// dx.doi.org/10.1590/s0085-56262011000400016.

BIHN, J. H., M. VERHAAGH \& R. BRANDL, 2008. Ecological stoichiometry along a gradient of forest succession: bait preferences of litter ants. Biotropica 40(5): 597-599. DOI: https://doi. org/10.1111/j.1744-7429.2008.00423.x.

BLÜTHGEN, N. \& K. FIEDLER, 2004. Preferences for sugars and amino acids and their conditionality in a diverse nectar-feeding ant community. Journal of Animal Ecology 73(1): 155-166. DOI: https:// doi.org/10.1111/j.1365-2656.2004.00789.x.

BOLTON, B., 2018. AntWeb: ants of Bolton world catalog. Available from: https://www.antweb.org/project.do? name=worldants. Accessed in: October 18, 2019.

BREED, M., 2015. When is there not enough salt for ants? Insectes Sociaux 62(2): 119-120. DOI: https://doi.org/10.1007/s00040-0150405-7.
CSATA, E. \& A. DUSSUTOUR, 2019. Nutrient regulation in ants (Hymenoptera: Formicidae): a review. Myrmecological News 29: 111-124. DOI: https://doi.org/10.25849/myrmecol.news_029:111.

DINIZ, K. S. \& V. V. SCUDELLER, 2005. Estrutura fitossociológica de uma floresta de terra firme na Amazônia Central. In: N. E. SANTOS-SILVA, F. M. APRILE, V. V. SCUDELLE \& E. S. MELO (Ed.): Diversidade biológica e sociocultural do Baixo Rio Negro, Amazônia Central: 155-167. Editora INPA, Manaus.

DORIAN, N. N. \& R. E. BONOAN, 2016. Salt foraging of stingless bees at La Selva Biological Station, Costa Rica. Bee World 93(3): 61-63. DOI: https://doi.org/10.1080/0005772X.2016.1229099.

DUDLEY, R., M. KASPARI \& S. P. YANOVIAK, 2012. Lust for salt in the Western Amazon. Biotropica 44(1): 6-9. DOI: https://doi. org/10.1111/j.1744-7429.2011.00818.x.

DUSSUTOUR, A. \& S. J. SIMPSON, 2008. Carbohydrate regulation in relation to colony growth in ants. Journal of Experimental Biology 211(14): 2224-2232. DOI: https://doi.org/10.1242/jeb.017509.

FELDHAAR, H., 2014. Ant nutritional ecology: linking the nutritional niche plasticity on individual and colony-level to community ecology. Current Opinion in Insect Science 5: 25-30. DOI: https://doi. org/10.1016/j.cois.2014.09.007.

FERNÁNDEZ, F., 2003. Introducción a las hormigas de la región Neotropical: 1-398. Instituto de Investigación de Recursos Biológicos Alexander von Humboldt, Bogotá.

FIALA, B. \& K. E. LINSENMAIR, 1995. Distribution and abundance of plants with extrafloral nectaries in the woody flora of a lowland primary forest in Malaysia. Biodiversity \& Conservation 4(2): 165182. DOI: https://doi.org/10.1007/BF00137783.

HARADA, A. Y., 2016. State of art of ants (Hymenoptera: Formicidae) at Caxiuanã, Melgaço, Pará, Brazil. Advances in Entomology 4: 115-132. DOI: http://doi.org/10.4236/ae.2016.43013.

HÖLLDOBLER, B. \& E. O. WILSON, 1990. The ants: 1-732. Harvard University Press, Cambridge, Massachusetts.

INSTITUTO CHICO MENDES DE CONSERVAÇÃO DA BIODIVERSIDADE (ICMBio), 2012. Plano de manejo da Floresta Nacional de Caxiuanã: Vol I-Diagóstico. ICMBio, Brasília.

KASPARI, M., S. P. YANOVIAK \& R. DUDLEY, 2008. On the biogeography of salt limitation: a study of ant communities. Proceedings of the National Academy of Sciences of the United States of America 105(46): 17848-17851. DOI: https://doi. org/10.1073/pnas.0804528105.

KASPARI, M., S. P. YANOVIAK, R. DUDLEY, M. YUAN \& N. A. CLAY, 2009. Sodium shortage as a constraint on the carbon cycle in an inland tropical rainforest. Proceedings of the National Academy of Sciences of the United States of America 106(46): 19405-19409. DOI: https://doi.org/10.1073/pnas.0906448106. 
KASPARI, M., E. A. R WELTI \& K. M. BEURS, 2019. The nutritional geography of ants: Gradients of sodium and sugar limitation across North American grasslands. Journal of Animal Ecology 86(2): 1-9. DOI: https://doi.org/10.1111/1365-2656.13120.

LANZA, J., E. L. VARGO, S. PULIM \& Y. Z. CHANG, 1993. Preferences of the fire ants Solenopsis invicta and S. geminata (Hymenoptera: Formicidae) for amino acid and sugar components of extrafloral nectars. Environmental Entomology 22(2): 411-417. DOI: https://doi.org/10.1093/ee/22.2.411.

LEGENDRE, P. \& L. LEGENDRE, 2012. Numerical ecology: 1-969. Elsevier, Amsterdam.

LISBOA, P. L. B. \& M. G. FERRAZ, 1999. Estação Científica Ferreira Penna: ciência e desenvolvimento sustentável na Amazônia. Museu Paraense Emílio Goeldi, Belém.

LONGINO, J. I., J. A. CODDINGTON \& R. K. COLWELL, 2002. The ant fauna of a tropical rainforest: estimating species richness three different ways. Ecology 83(3): 689-702. DOI: https://doi. org/10.2307/3071874.

MCGLYNN, T. P., D. J. SALINAS, R. R. DUNN, T. E. WOOD, D. LAWRENCE \& D. A. CLARK, 2007. Phosphorus limits tropical rain forest litter fauna. Biotropica 39(1): 50-53. DOI: https://doi. org/10.1111/j.1744-7429.2006.00241.x.

MOREIRA, A., L. A. C. MORAES \& N. K. FAGERIA, 2012. Nutritional limitations in multi-strata agroforestry system with native Amazonian plants. Journal of Plant Nutrition 35(12): 1791-1805. DOI: https:// doi.org/10.1080/01904167.2012.706676.

NYAMUKONDIWA, C. \& P.ADDISON, 2014. Food preference and foraging activity of ants: recommendations for field applications of low-toxicity baits. Journal of Insect Science 14(1): 48. DOI: https:// doi.org/10.1093/jis/14.1.48.

O'DONNELL, S., J. M. GARCÍA-C., J. BEARD, T. CHIWOCHA, D. LEWIS, C. LIU, H. PHILLIPS \& T. WILLIAMS, 2010. Leaf cutter ants (Atta cephalotes) harvest baits offering sodium chloride rewards. Insectes Sociau 57: 205-208. DOI: https://doi.org/10.1007/s00040010-0069-2.

OKSANEN, J., F. GUILLAUME-BLANCHET, M. FRIENDLY, K. KINDT, P. LEGENDRE, D. MCGLINN, P. MINCHIN, R. B. O'HARA, G. L. SIMPSON, SOLYMOS, H. STEVENS, E. SZOECS \& H. WAGNER, 2018. vegan: Community Ecology Package. R package. version 2.5-2. Available from: https://CRAN.R-project.org/ package= vegan. Accessed in: December 26, 2019.

OLIVEIRA, P. S. \& C. R. F. BRANDÃO, 1991. The ant community associated with extrafloral nectaries in the Brazilian cerrados. In: D. F. CUTLER \& C. R. HUXLEY (Ed.): Ant-plant interactions: 198-212. Oxford University Press, Oxford.
OLIVEIRA, L. L., C. F. FERREIRA, A. C. BRAGA \& A. PANTOJA, 2008. Precipitação efetiva e interceptação em Caxiuanã, na Amazônia Oriental. Acta Amazonica 38(4): 723-732. DOI: https://doi. org/10.1590/S0044-59672008000400016.

PEÑA-VENEGAS, C. P. \& G. C. VANEGAS, 2010. Dinámica de suelos amazónicos procesos de degradación y alternativas para su recuperación: 1-122. Instituto Amazónico de Investigaciones Científicas "SINCHI", Bogotá.

R DEVELOPMENT CORE TEAM, 2018. R: a language and environment for statistical computing. R Foundation for Statistical Computing, Vienna, Austria. Available from: https://www.R-project. org/. Accessed in: December 26, 2019.

SCHMIDT, F. A. \& E. DIEHL, 2008. What is the effect of soil use on ant communities? Neotropical Entomology 37: 381-388. DOI: https:// doi.org/10.1590/S1519-566X2008000400005.

SCHUPP, E. W. \& D. H. FEENER, 1991. Phylogeny, lifeform, and habitat dependence of ant-defended plants in a Panamanian forest. In: C. R. HUXLEY \& D. K. CULVER (Ed.): Ant-plant interactions: 175-195. Oxford University Press, Oxford.

SILVA, R. R. \& C. R. F. BRANDÃO, 2014. Ecosystem-wide morphological structure of leaf-litter ant communities along a tropical latitudinal gradient. PloS One 9(3). DOI: https://doi.org/10.1371/ journal.pone.0093049.

TINTI, J. M. \& C. NOFRE, 2001. Responses of the ant Lasius niger to various compounds perceived as sweet in humans: a structure-activity relationship study. Chemical Senses 26(3): 231-237. DOI: https://doi. org/10.1093/chemse/26.3.231.

VICENTE, R. E., A. C. FERREIRA, R. C. L. SANTOS \& L. P. PRADO, 2018. Ants (Hymenoptera: Formicidae) from an Amazonian fragmented landscape, Juara, Mato Grosso, Brazil, with new records of ant species. Papéis Avulsos de Zoologia 58: e20185840. DOI: https://doi.org/10.11606/1807-0205/2018.58.40.

VIEIRA, J. \& H. L. VASCONCELOS, 2014. Inter-generic and interhabitat variation in the demand for sodium by Neotropical ants. Insectes Sociaux 62(2): 133-140. DOI: https://doi.org/10.1007/ s00040-014-0382-2.

WICKHAM, H., 2016. ggplot2: elegant graphics for data analysis: 1-259. Springer, Texas.

YAVITT, J. B., K. E. HARMS, M. N. GARCIA, S. J. WRIGHT, F. HE \& M. J. MIRABELLO, 2009. Spatial heterogeneity of soil chemical properties in a lowland tropical moist forest, Panama. Australian Journal of Soil Research 47(7): 674-687. DOI: https://doi. org/10.1071/SR08258.

ZAR, J. H., 2010. Biostatistical analysis: 1-931. Prentice-Hall, USA.

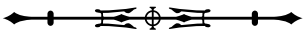


